\title{
Strengthening the State Defense System of the Republic of Indonesia through Implementation of the State Defense Policy
}

\author{
Hermina Manihuruk \\ Universitas Pembangunan Nasional Veteran Jakarta \\ hermina@upnvj.ac.id
}

\begin{abstract}
Defending the state is the attitude and actions of citizens based on love for the country, awareness of the nation and state, belief in Pancasila as the ideology of the nation and state, willingness to sacrifice to face threats, challenges, obstacles, and disturbances (ATHG). To achieve national goals, the Astra gatra composing National Resilience requires an integrated implementation system that refers to geopolitical dynamics. This integrated system can be stated in a state defense system that already has a strong legal basis in the 1945 Constitution, as well as Law Number 3 of 2002 concerning State Defense (Law No. 3/2002), Article 9 of Law Number 3 of 2002. Law -The State Defense Law also classifies state defense into three groups, namely the Main Component (TNI), Reserve Component, and Supporting Component. In implementing state defense, a citizen can do it both physically and non-physically. Physical state defense includes struggling to take up arms when there is an attack from a foreign country against national sovereignty. Thus, it is necessary to further study the implementation of existing policies regarding state defense, as an effort to strengthen the state defense system of the Republic of Indonesia. This writing using qualitative research methods.
\end{abstract}

Keywords: state defense, defense, policy

\section{INTRODUCTION}

The survival and existence of a nation are greatly influenced by the nation's ability to understand and master the geographical conditions and the surrounding environment. The growth and development or reduction of the nation's living space are also influenced by the geopolitical view that is believed by the entity of a nation. As the world's largest archipelagic country, Indonesia's geographic position stretches to the coordinates of $6 \mathrm{~N}-11.08$ 'latitude and $95 \mathrm{E}$ - 141.45' East longitude and is located between 2 (two) continents, Asia in the north, Australia in the South, and 2 (two) oceans, namely Indies / Indonesia in the west and the Pacific in the east.

From a geopolitical perspective, this stretch of geographical position certainly makes Indonesia a country that has a strategic bargaining power and bargaining position in the field and relations between nations, both in the regional and global scope. This departs from the idea that space is the core of geopolitics because it is a container for political and military 
dynamics. The de facto and de jure control of space is the legitimacy of political power.

Increasing state-space or decreasing state space by various types of reasons is always associated with the honor and sovereignty of the state and nation (Darmadi, 2010). Meanwhile, relations between nations are always colored by competition and cooperation. In this connection, every nation strives to achieve and secure its national interests using all instruments of national power at its disposal. It is to national interests that the Indonesian nation of course must always develop and have space consciousness and geographical awareness as an archipelagic country.

This is logical and very basic, considering that on the one hand, a strategic and open geographical position and containing a variety of potential sources of natural wealth, is certainly an opportunity and an advantage for the Indonesian nation in realizing its national ideals and goals. However, on the other hand, the geographical position that becomes the crossroads and meeting of the interests of various countries contains vulnerabilities and vulnerabilities due to the influence of strategic environmental developments that can develop into a threat to national resilience and national defense.

Apart from that, the diversity of ethnic groups in Indonesia is also an asset for the Indonesian nation, because it can be formed as an element of magnification of the Indonesian nation so that it is known by other nations because of its diversity. But on the other hand, this diversity can be a threat to the Indonesian nation. This is because of the different principles of life and local culture which are of course different. Ideally, even though they vary in ethnicity, religion, race, and others, Indonesian citizens should still understand their rights and obligations as Indonesian citizens to participate in maintaining unity and integrity and participate in the defense of the state.

State defense is the attitude and actions of citizens who are based on love for the country, awareness of the nation and state, belief in Pancasila as the ideology of the nation and state, willingness to sacrifice to face threats, challenges, obstacles, and disturbances (ATHG) both from within and from outside which endanger the survival of the nation and state, territorial integrity, national jurisdiction and the noble values of Pancasila and the 1945 Constitution as the state constitution (Winarno, 2013). This definition certainly provides the widest possible opportunity for every citizen to be able to carry out state defense activities by their respective abilities in their respective fields.

The achievement of national goals is also very much influenced by geopolitical dynamics and insights from the archipelago or the Indonesian perspective on itself and the environment in which it exists. To be able to anticipate geopolitical dynamics to achieve national goals, a toughness or resilience that departs from the Archipelago is required. In this context, the Indonesian nation needs resilience to National Resilience, namely the dynamic condition of the Indonesian nation which includes all aspects of national life which are integrated and contain tenacity and resilience which contains the ability to develop national strength in facing and overcoming all 
challenges, threats, obstacles, and disturbances both. that comes from outside as well as from within, to guarantee identity, integrity, the survival of the nation and state, and the struggle to achieve its national goals.

To achieve national goals, the Astra gatra composing National Resilience requires an integrated implementation system that refers to geopolitical dynamics. This integrated system can be stated in a state defense system that already has a strong legal foundation in the 1945 Constitution, as well as Law Number 3 of 2002 concerning State Defense (Law No. 3/2002), Article 9 of Law Number 3 of 2002. Concept State defense itself implies participation in state defense, which includes: defending the independence and sovereignty of the state, territorial integrity, and national safety from all threats. Meanwhile, the form of defense of the state is in the form of rights and obligations through civic education, service as a TNI soldier, and service according to the profession. Even though it already has a solid legal foundation, until now Indonesia does not yet have a comprehensive system for implementing state defense.

From a regional perspective, the meaning of state defense is an attitude and action of people (residents) from wherever they come from (native / immigrant) who live in a certain area to protect, protect, and be responsible for the sustainability of their territory. In the perspective of citizenship law, the meaning of defending the state is related to the legal status of citizens (WNI and WNA), meaning that those who have the right and obligation to defend the state are Indonesian citizens (WNI). In the context of the aspect of national resilience, the meaning of state defense becomes attitudes and actions that reflect the strength and resilience of a nation and state in protecting and protecting the territory of the country as a whole. Currently defending the state is intended to strengthen the sense of nationalism and the spirit of patriotism of Indonesian citizens amidst threats to the nation in the form of crimes of international and national terrorism, acts of violence that smell of SARA, violations of state territory both on land, sea, air and outer space, separatist movements, transnational crimes and disturbances, and environmental destruction.

In-Law No. 3/2002 on National Defense, it is emphasized that as a manifestation of universality, the involvement of all citizens in efforts to defend the state is both an obligation and a right. The Law on National Defense also classifies state defense into three groups, namely the Main Component (TNI), Reserve Component, and Support Component. In implementing state defense, a citizen can do it both physically and non-physically. Physical state defense includes struggling to take up arms when there is an attack from a foreign country against national sovereignty. Meanwhile, non-physical state defense is defined as all efforts to protect the nation and state sovereignty through a process of increasing nationalism. Nationalism is a series of love and awareness in the process of living in the state and nation, as well as efforts to foster a sense of love for the country. Besides, the defense can be done by fostering activeness in playing an active role 
in realizing the progress of the nation and state.

In Indonesia, the state defense process has been formally regulated into law. Among them have been stated in Pancasila and the 1945 Constitution, especially Article 30. In this article, it is explained that defending the nation is the obligation of all Indonesian people without exception. One of the functions of the state which is very important for ensuring the survival of the state is the function of national defense. The state defense function is primarily intended to guard and defend the country from all possible attacks from outside. Therefore, it must be equipped with defense equipment, namely the TNI (Indonesian National Army) and its equipment. The TNI consists of the Army, the Navy, and the Air Force. Apart from the defense function, another function that is also very important in the effort to defend the state is the security function (order), which is to prevent clashes in society. To carry out this security function in our country an institution known as POLRI was formed.

\section{METHOD}

The type of research used is normative legal research, by examining the law as norms, rules contained in the Book of Law, and various statutory regulations. This research is conducted by reviewing library materials and can also be referred to as doctrinal research because it uses statutory regulations, court decisions, and expert opinion. The approach to the problem used in this study is a normative juridical approach. For this reason, research is needed by looking at the main plan in the development of science. This is done by studying and examining books, literary materials relating to legal principles, legal doctrines, legal principles, and legal systems in the problem, namely regarding the implementation of the state defense policy to strengthen the national defense system.

Sources of data used in this study are secondary data sources. Secondary data is data that includes laws and regulations, policies, official documents, books, research results in the form of reports or journals, and others (Soekanto, 1986). The secondary data in this study were obtained from scientific books, expert opinions, and literature that are in line with the research theme. The form of research conducted in this writing is qualitative research. Where this research applies to humanistic or interpretive knowledge which technically emphasizes the text and this research is a series of scientific activities in the context of problem-solving (Nata, 2003). In this case, the author uses statutory regulations, government policies, books, then performs analysis to obtain the necessary data.

\section{RESULT AND DISCUSSION}

Philosophically, state defense is an implementation of social contract theory or social agreement theory about the formation of the state. In the view of the social contract theorists, it is stated that the state is formed because of the desire of citizens or the community to protect their rights and obligations in social life so that harmonious, peaceful, and peaceful relationships are established (Kohn, 1984). Every citizen has an interest, each interest must have the 
potential to create a conflict of interest in the community. The state is presented by an agreement or agreement between citizens in the community to protect the rights and obligations of citizens and to ensure that there are no conflicts of interest between individuals in society.

In this context, the state has a very noble goal, which is to align the interests of citizens amid community interactions. The state guarantees rights and obligations that are carried out in a peaceful, safe, and harmonious manner in society. To ensure that this goal is achieved, the state makes rules of the game, regulations, and legal rules that regulate the rights and obligations of citizens relating to the state as well as the imposition of sanctions or penalties for any citizen who violates these regulations or legal rules.

Citizens are asked to comply with all these rules and citizens who violate the rules will be given sanctions, while citizens who obey the rules will be given rewards. In this connection, it is very clear that the state was born because of an agreement between citizens. The state is a product made by citizens. The existence of a state because of the agreement of the citizens. The state will be strong and strong if it is defended by citizens because citizens are the parties who designed the formation of the state. It is very logical and reasonable for the state to be defended by citizens. The reason is that the state is made by citizens so that when the state needs help to be defended, the citizens must defend the country whenever and wherever. Also, defending the country must be done because defending the state is a reciprocal action between the relationship of the state and citizens.

The state is present in the world to protect the alignment of interests between citizens, while citizens must respond by defending the state when the state needs defense. The relationship between the state and citizens in the context of defending the state is reciprocal. The state needs citizens, while citizens need the state. Between citizens and the state need each other, complement each other, and complement each other. The relationship between the state and citizens is complementary so that it can provide strong and formidable strength if the two parties unite to build the building of the nation-state. The state will be strong and strong if its citizens unite and solidly defend the country. Citizens will be comfortable, safe, peaceful, and prosperous if the state is strong and strong because of the strong security guarantees from the state.

The 1945 Constitution of the Republic of Indonesia (UUD 1945) regulates State Defense Efforts, namely the provisions of Article 27 Paragraph (3): "Every citizen has the right and obligation to participate in efforts to defend the State," and Article 30 paragraph (1): "Every citizen has the right and duty to participate in the defense and security of the country." Efforts to defend the state must be carried out in the framework of fostering awareness of state defense as an effort to realize Indonesian citizens who understand and live and are confident to fulfill their rights and obligations. The Indonesian nation also wants to have a superior and noble civilization. Such civilization can be achieved if our society and nation is also a 
good society and nation, peaceful, just, and prosperous, as has been mandated by the founding fathers in the Preamble to the 1945 Constitution.

On the other hand, the 1945 Constitution provides a foundation and direction in the development of the system and administration of national defense. The substance of state defense contained in the 1945 Constitution includes the views of the Indonesian people in seeing themselves and their environment, the objectives of the state, the state defense system, and the involvement of citizens. This reflects the attitude of the Indonesian nation which is against all forms of colonialism, which are against the values of humanity, justice, and welfare. Furthermore, the 1945 Constitution stipulates the State Defense System (Sishanneg) which places the people as a vital role, and national defense is carried out with the Universal People's Defense and Security System (Sishankamrata). Then the Sishankamrata was translated into Sishanneg, becoming Sishanneg which was universal.

State Defense is all efforts to defend the sovereignty of the country, the territorial integrity of the Republic of Indonesia, and the safety of the entire nation from threats and disturbances to the integrity of the nation and state. The meaning contained in Sishankamrata: "the people are the foremost and in universality," either in spirit or in utilizing all national strength and resources, for defense purposes in defending the existence of the Republic of Indonesia. The participation of the people in Sishanneg is the implementation of the realization of the rights and obligations of every citizen to participate in national defense efforts. The participation of citizens in national defense is a form of honor for citizens to reflect on their rights. The participation of citizens in national defense efforts can be direct, namely becoming voluntary soldiers of the Indonesian National Army (TNI), but can also indirectly, namely in their respective professions that contribute to national defense (including educators) or become mandatory soldiers.

State defense is one of the formers of the identity and personality of the Indonesian nation that is responsible, aware of the rights and obligations as citizens, loves the homeland, to be able to display patriotic attitudes and behaviors in the form of state defense. A patriotic spirit for the sake of the nation and state that appears in the attitudes and behavior of citizens, who are aware that defending the country is the building of the strength of state defense in Sishanneg.

The implementation of state defense has been regulated in Law No. 3 of 2002 concerning National Defense. Where it is explained that State Defense is the attitude and behavior of citizens who are animated by their love for the Unitary State of the Republic of Indonesia which is based on Pancasila and the 1945 Constitution in establishing the survival of the nation and state as a whole. Meanwhile, state defense is the right and obligation of every citizen (Budimansyah, 2006). Implementation in Article 9 paragraph (2) of Law Number 3 of 2002 explains that efforts to defend the state can be carried out through:

a. Citizenship Education 
Is one of the materials or studies that must be included in the curriculum for basic education to higher education (Article 37 paragraph (1) and (2) of Law Number 20 of 2003 concerning the national education system). Citizenship education is intended to shape students into human beings who have a sense of nationality and love for the country. We can also see by tracing the juridical provisions of the explanation of Article 9 paragraph (2) letter an of Law no. 3 of 2002, which reads "in civic education, an understanding of awareness of state defense is included" (Subagyo, 2015). This means that one of the ways to gain an understanding of the awareness of state defense can be pursued by participating in civic education.

b. Mandatory Basic Military Training Apart from the TNI, one of the components of citizens who receive basic military training is the student element formed in the student regiment organization (Menwa). Entering a student regimental organization is the right of every student, but after entering the organization they must follow basic military training. Members of the student regiment are components of the nation who already have an understanding of the basics of the military and can be utilized in defending the state.

The hope is that with compulsory basic military training activities, the initial ability to defend the state in the sense that it can be prepared and empowered as a supporting component and a reserve component that will be implemented with full awareness to defend the country. Not only for students, but basic military training can be carried out by all components of the nation.

For this reason, other national components, in this case, the government apparatus, can carry out basic mandatory military training to shape morals as a state apparatus. This can be done through disciplinary and leadership training. While the cultivation of the values of state defense in early childhood education and basic education can be done through games/games in schools, Scouting activities, and concrete activities related to love for the country. This is consistent with A.M. Hendropriyono, former Head of BIN, who said that Sishanneg should not only be described with the awareness of defending the country but by imposing military service. Military service is a concrete form of implementing state defense (Hendropriyono, 2013). 
State defense and military service are closely related to one another, constituting one of the means or instruments for implementing state defense. However, the implementation of the state defense program in Indonesia raises the pros and cons of compulsory military service and the absence of regulations on the implementation of compulsory military service in Indonesia. The state defense policy in the form of compulsory military service for all citizens has been implemented, such as the United States, Russia, Britain, Malaysia, Singapore, and other countries. Even citizens who are female are obliged to join the military service, such as in Israel, South Korea, and Suriname.

c. Devotion as the Indonesian National Armed Forces (TNI) voluntarily or compulsorily

In line with the demands for reform, today there is also a separation of the roles and functions of the TNI and POLRI. POLRI plays a role in the field of state security, while the TNI plays a role in the field of national defense. The TNI is a major component in national defense. If it is in the form of a military threat, then of course the TNI will be placed as the main component. However, if the threat is non-military, then the main element is government institutions outside the field of defense according to the form and type of threat being faced supported by other elements of the nation's power.

d. Appropriate devotion Profession Is devoted citizens with certain professions in the interests of national defense (Sumarsono, 2005). This includes overcoming and/or minimizing the consequences of war, natural disasters, or other disasters. This is by the explanation of Law No.3 of 2002. Based on this explanation, some of these professions can be identified, especially those related to activities to overcome or minimize the consequences of war, natural disasters, or other disasters, namely, among others, Indonesian Red Cross officers, medics, teams SAR, Police, and other social assistance officers. Hopefully, with a profession that has this ability, at any time it can be empowered as a reserve component and a supporting component. For this reason, in improving the human resources of each of these professions, it is necessary to train and be educated with state defense material. This is to instill the values of state defense in every profession. Thus, citizens of this profession have the right and obligation to participate in efforts to defend the state by their 
respective professional duties. Community groups who have professions must actively participate in overcoming and helping people who are in trouble by promoting the cooperative attitude that is characteristic of the Indonesian nation.

Of the four ways, it is not surprising that in the end state defense is always associated with the military and taking up arms. Because the law itself also regulates this. But defending the country is not only by taking up arms or fighting. State defense has been the character of the nation since time immemorial. It's just that the understanding and application vary in each era. As in the era of the war for independence (1945-1949), state defense is defined as the participation of citizens in the war to defend independence (Nur, 2015). At that time, taking up arms was the most appropriate thing to do as a form of protecting the country. Then when times began to change and entered the New Order, state defense was more focused on national resilience to face obstacles, challenges, threats, and disturbances. However, if it is related to the current situation, of course taking up arms is no longer the right thing to do because Indonesia is no longer in a state of war emergency.

Therefore, it is necessary to reexamine what is meant by defending the country. Although not from the military. Although we do not have weapons and do not have the basic capabilities to fight, we are still obliged and entitled to defend the country. The easiest way to study is to analyze each of us. Have we implemented at least one of the elements of state defense that have been listed in Law No. 3 of 2002:

a. Love the homeland Love for the motherland is a feeling that arises in the heart and soul of a citizen to serve, care for, defend, protect his homeland from all threats and disturbances. In this case, it can also be interpreted as a sense of pride, sense of belonging, respect, respect, and loyalty that each individual has in the country where he lives as reflected in the behavior of defending his homeland, protecting and protecting his homeland, willing to sacrifice for the sake of the nation and his country, loves the customs or culture that exists in his country by preserving it and preserving nature and the environment.

b. Nation and State Awareness Realizing that we are in a place that has the same language, religion, ideology, culture, and/or history and has rules in the political, military, economic, social, and cultural fields regulated by the State.

c. Convinced of the Pancasila as the State Ideology

The state ideology or the nation's way of life is a frame of reference used by a country in managing its life. Believing in Pancasila as the State Ideology means that we wholeheartedly believe in Pancasila as the basis 
of the rules and order of our lives. Understanding the essence or value in Pancasila, implementing the values of Pancasila in everyday life, making Pancasila the unifier of the nation and state.

d. Sacrificing willing to Nation Willing means willing to be happy, and not expecting a reward based on one's own accord. Sacrificing means giving everything one has even if it causes suffering for oneself. A self-sacrificing attitude is an attitude that reflects the willingness and sincerity of giving something that is owed to others, even though it will cause suffering for himself.

e. Had initial State Defense Capabilities

The initial ability to defend the country can be interpreted psychologically or physically. Psychologically, namely having emotional, spiritual, and intellectual intelligence, always nurturing his body and soul, and having the characteristics of discipline, resilience, and hard work. Meanwhile, physically, namely having a health condition, physical skills to support the initial ability of mental development by being fond of exercising and maintaining health.

From the description above, we can conclude that the implementation of state defense is not always about the military. All that we can start from ourselves, the smallest environment around us. The most important thing is how we understand our extension as citizens who are obliged to participate in efforts to defend the country.

The essence of State Defense is all defense efforts that are universal in nature, the implementation of which is based on awareness of the rights and obligations of citizens as well as confidence in their strength. The universal nature of the implementation includes all citizens, territories, and other national resources, and is prepared early by the government and is carried out in a total, integrated, directed, and continuous manner to uphold state sovereignty, territorial integrity, and the safety of the entire nation from all threats. All national resources in the form of human resources, natural and man-made resources, values, technology, infrastructure, and funds can be utilized to improve the national defense capacity. Potential national resources are all resources that can be utilized through a process of transformation into a potential national defense force which, when needed, can be used to increase the national defense force.

One of the ways to transform national resources into potential state defense forces is to build a reserve and supporting components, to strengthen and enlarge the main components of national defense. State defense can be seen at micro and macro according to the country of each element of life. On a micro level, the implementation of state defense is manifested by every element of life in the form of defense of the place where the feet 
stand and where living as living expenses is obtained. This means, there will be resistance to any intervention that comes from other countries. In simple language, it can be stated that determining life choices is a right. However, after making a choice, there is an obligation that must be fulfilled. Fulfilling the duty of life as a human being with dignity at the place where our feet stand is the microform of state defense.

At a macro level, the form of state defense is manifested by the ability to mobilize all supporting elements to achieve a common goal, namely the realization of a just, prosperous, safe, peaceful, harmonious, peaceful, happy and prosperous society. Thus, decision-making is carried out unanimously so that there is no place to escape responsibility. State defense must be understood in a broad context where every citizen is an entity that lives in a state building so that essentially citizens are obliged to maintain, maintain and protect every state institution, institution, and apparatus. The state must be defended to the death if indeed the country is a mandate in running its government. There is no reason for citizens to evade and escape from the obligation to defend the country. Citizens must be obedient, loyal, obedient, and subject to any regulations made by the state to promote state defense.

According to the regulations, defending the country is a policy. As a policy, defending the country certainly has a legal basis, juridical foundation, and proper and valid regulations. State defense is a policy made by the state or government which aims to protect the country from enemy threats, either directly or indirectly.
1) Law of the Republic of Indonesia Number 3 of 2002 on State Defense.

Article 9 paragraph (1) states that every citizen has the right and obligation to participate in efforts to defend the state which are manifested in the implementation of state defense. The state defense system is a defense system that is universal, namely a defense system that involves all citizens, territories, and other national resources, and is prepared early by the government and is carried out in a total, integrated, directed, and continuous manner to uphold state sovereignty, territorial integrity and the safety of the entire nation from all forms of threats (Suseno, 2000). Furthermore, it is emphasized in Article 9 paragraph (2) that the participation of citizens in efforts to defend the state, as referred to in paragraph (1), is carried out through:

a. civic education;

b. compulsory basic military training;

c. voluntary or compulsory service as soldiers of the Indonesian National Army; and

d. service according to the profession.

The awareness of defending the state is an essential thing and must be possessed by every 
Indonesian citizen (WNI), as a form of fulfilling their rights and obligations to defend the country. In the explanation of Law of the Republic of Indonesia Number 3 of 2002 concerning State Defense Article 9 paragraph (1) it is stated that: "Efforts to defend the state are the attitudes and behavior of citizens who are imbued with their love for the Unitary State of the Republic of Indonesia based on Pancasila and the Law. 1945 basis in ensuring the survival of the nation and state. Efforts to defend the state, apart from being a basic human obligation, are also an honor for every citizen which is carried out with full awareness, responsibility, and willingness to sacrifice in the service of the state and nation. "From this explanation directs every citizen to always increase motivation to strengthen nationalism and the spirit of patriotism. Therefore, citizens participate in education, training, and service to the nation and homeland in various professions that are carried out.

2) Law of the Republic of Indonesia Number 39 of 2009 on Human Rights.

Article 68 states that "Every citizen is obliged to participate in efforts to defend the state by the provisions of laws and regulations". The history of the Indonesian nation records various sufferings, misery, and social inequalities caused by unfair and discriminatory behavior based on ethnicity, race, color, culture, language, religion, class, gender, and other social status. Such unfair and discriminatory behavior is a violation of human rights, both vertical and horizontal. Therefore, as the obligation of citizens to participate in efforts to defend the state, it becomes the starting point and goal in organizing the life of the community, nation, and state.

3) Law of the Republic of Indonesia Number 20 of 1982 on Basic Provisions for the Defense and Security of the Republic of Indonesia.

Starting from Article 17 to Article 25 concerning the Rights and Obligations of Citizens in State Defense. By the provisions in this Law, that the rights and obligations of citizens are realized by participating in efforts to defend the state which are carried out through preliminary state defense education which is inseparable from the national education system. Starting from the early stages of education at the basic level to the secondary level in the Scout movement activities, and later in the form of civic education at the higher education level. Therefore, the 
implementation of the state defense program can be done physically through the enactment of the Reserve Components Law. Also, it is a form of citizen participation in efforts to defend the state compulsorily which shows its universality and versatility in the implementation of state defense and security through trained people. Trained people are nurtured according to their educational environment, residential environment, or work environment. This is by the concept of state defense which will be declared per the respective environment and region.

4) Nawacita

President Joko Widodo to prioritize changes to an Indonesia that is politically sovereign, economically independent, and has a cultural personality. The ninth point is "reinforcing diversity and strengthening Indonesia's social restoration through policies to strengthen diversity education and creating spaces for dialogue between citizens".

Therefore, the young generation as strategic human resources needs to be equipped with basic human values, fighting power, and nationalism. For this reason, learning to defend the country in the world of education continues to be activated. By learning to defend the country, it is hoped that it can increase the abilities given from each field of science with the ability to feel and behave more integratively between the disciplines being taught. Furthermore, it can strengthen the character of the younger generation to take part in the workforce by bringing noble values and national values.

The implementation of state defense carried out by the younger generation in Indonesia is still not optimal. This is due to the low awareness of state defense that young people have. Most of the youth in Indonesia have not taken part in achievements that can be proud of for the progress of the Indonesian nation and state. Most of the youth spend more time on activities that are not productive. Article 27 paragraph (3) of the 1945 Constitution states that every citizen has the right and obligation to participate in efforts to defend the state. The concept of state defense can be described, namely physically and nonphysically. Physically, namely by carrying a weapon against enemy attacks or aggression. Defending the country physically is done to deal with external threats. Meanwhile, non-physical state defense can be defined as any effort to defend the unitary state of the Republic of Indonesia by increasing awareness of the nation and state, instilling love for the homeland, and playing an active role in advancing the nation and state. 


\section{CONCLUSION \\ Implementation of State Defense}

Policies in Strengthening the Unitary State Defense System of the Republic of Indonesia (NKRI): regulated in Law No. 3 of 2002 concerning National Defense. Where it is explained that State Defense is the attitude and behavior of citizens who are animated by their love for the Unitary State of the Republic of Indonesia which is based on Pancasila and the 1945 Constitution in establishing the survival of the nation and state as a whole. Meanwhile, defending the state is the right and obligation of every citizen. Implementation in article 9 paragraph (2) of Law Number 3 of 2002 explains that efforts to defend the state can be carried out through Citizenship education, mandatory basic military training, voluntary or compulsory service as a soldier of the Indonesian National Army, and service according to the profession.

\section{REFERENCES}

[1]. Budimansyah, D. (2006). Mari Berpartisipasi dalam Bela Negara. Bandung: Ganesindo.

[2]. Darmadi, H. (2010). Pengantar Pendidikan Kewarganegaraan. Bandung: Alfabeta.

[3]. Hendropriyono, A. (2013). Filsafat Intelejen Negara Republik Indonesia. Jakarta: Gudang Penerbit.

[4]. Kohn, H. (1984). Nasionalisme Arti dan Sejarahnya. Jakarta: Erlangga.

[5]. Nata, A. (2003). Metodologi Studi Islam. Jakarta: Raja Grafindo Persada.

[6]. Nur, P. (2015). Resensi Buku Bela Negara. Bandung: Gramedia.

[7]. Soekanto, S. (1986). Pengantar Penelitian Hukum. Jakarta: UI Press.

[8]. Subagyo, A. (2015). Bela Negara: Peluang dan Tatanan di Era Globalisasi. Yogyakarta: Graha Ilmu.

[9]. Sumarsono. (2005). Pendidikan Kewarganegaraan. Jakarta: Gramedia Pustaka.

[10]. Suseno, A. (2000). Strategi Pembudayaan Kesadaran Hak Bela Negara Tahun 2000-2004. Jakarta: Pustaka Sinar Harapan.
[11]. Winarno. (2013). Pembelajaran Pendidikan Kewarganegaraan. Jakarta: Bumi Aksara. 